\title{
STUDY OF NITROGEN USE EFFICIENCY AND YIELD OF RICE INFLUENCED BY DEEP PLACEMENT OF NITROGEN FERTILIZERS
}

\author{
R.S. Rea ${ }^{1^{*}}$, M.R. Islam ${ }^{2}$, M.M. Rahman ${ }^{2}$ and K. Mix ${ }^{1}$ \\ ${ }^{1}$ Department of Agriculture, Texas State University, San Marcos, USA \\ ${ }^{2}$ Department of Soil Science, Bangladesh Agricultural University, Mymensingh, Bangladesh
}

\begin{abstract}
Continuous increase of nitrogen fertilizer use adversely affecting the soil health as well as the environment. It necessitates the systematic study of the impact of nitrogen $(\mathrm{N})$ fertilizer use-reduction on crop yield. In this article, the effects of deep placement of nitrogen fertilizers on nitrogen use efficiency (NUE) and yield of rice variety "BRRI dhan46" were investigated and compared for three $\mathrm{N}$ formulations: urea super granule (USG), NPK briquettes and prilled urea (PU). The experiment was conducted in randomized complete block design (RCBD) with eight $\mathrm{N}$ treatments replicated three times. The treatments were applied by varying doses $\left(0,52,78\right.$ and $\left.104 \mathrm{~kg} \mathrm{ha}^{-1}\right)$ of nitrogen fertilizers in a known identical soil and weather condition. Applications of PU, USG and NPK briquettes exhibited significant differences on yield attributes of rice. Results revealed maximum grain yield of $6.391 \mathrm{t} \mathrm{ha}^{-1}$ (54\% increases over control) for the dose USG $104 \mathrm{~kg} \mathrm{ha}^{-1}$ which is statistically similar to the dose USG $78 \mathrm{~kg} \mathrm{ha}^{-1}$ and NPK briquettes $104 \mathrm{~kg} \mathrm{ha}^{-1}$. The deep placement of USG and NPK briquettes enhanced both the recovery of applied $\mathrm{N}$ and $\mathrm{N}$ use efficiency compared to broadcast application of prilled urea. However, USG $78 \mathrm{~kg} \mathrm{ha}^{-1}$ showed maximum apparent $\mathrm{N}$ recovery, $\mathrm{N}$ use efficiency, gross margin and marginal benefit-cost ratio. Thus, an application of $78 \mathrm{~kg} \mathrm{ha}^{-1}$ USG can be recommended for profitable cultivation of rice variety BRRI dhan46.
\end{abstract}

Keywords: Apparent Nitrogen Recovery, Marginal Benefit-cost Ratio, Nitrogen use Efficiency, Prilled Urea, Urea Super Granule.

\section{INTRODUCTION}

Global demands for food and fiber will increase up to $70 \%$ by 2050 (Singh and Trivedi, 2017). An increase of $2 \%-3 \%$ year $^{-1}$ in rice production has to be maintained to ensure the self-sufficiency in rice, within limited arable land (Haque and Haque, 2016). Further, the use of chemical fertilizer has been rapidly increasing to meet the

*Corresponding author: r_r628@txstate.edu 
continuously growing demands of increased yield from the existing land. Particularly in highly populated developing countries, the increasing rate of fertilizer use is dramatic. However, this increased rate of fertilizer has negative impact on food safety, environment and soil health. It has been reported that, the use of excess $\mathrm{N}$ fertilizers increases $\mathrm{NO}_{3}-\mathrm{N}$ and $\mathrm{NH}_{4}-\mathrm{N}$ in underground water which is a threat for human health. Chemicals like $\mathrm{KCl}, \mathrm{NaNO}_{3}, \mathrm{~K}_{2} \mathrm{SO}_{4}, \mathrm{NH}_{4} \mathrm{Cl}$ etc. added in soil due to application of fertilizers are responsible for demolishing soil structure (Savci, 2012). Thus, it is important to minimize the use of chemical fertilizers.

Rice is a dominant crop of predominantly agriculture dependent countries of the world like Bangladesh, India, China, Vietnam etc. In Bangladesh, rice farmers rely solely upon urea fertilizer (about 57\%, 2.46 million MT, of total fertilizer use) and more than $50 \%$ of the total demand of urea is imported, which demands a large sums of foreign currency (BBS, 2015). Therefore, attention must be given to minimize the cost without compromising production.

Generally, the farmers of Bangladesh use urea fertilizer by broadcast method during cultivation. Most of this applied fertilizer is lost through leaching, surface runoff, $\mathrm{NH}_{4}^{+}$ and $\mathrm{NH}_{3}$ volatilization, denitrification, and other process. Consequently, $\mathrm{N}$ fertilizer use efficiency decreases. These losses of $\mathrm{N}$ result in reduced growth and yield of rice. Urea deep placement (UDP) is a proven technology that reduces $\mathrm{N}$ losses by up to $50 \%$ when compared with the conventional broadcast application of urea (Huda et al., 2016). Deep placement of nitrogenous fertilizers dissolves slowly in the soil providing a steady supply of nitrogen throughout the growing period of the crop. Deep placement of USG in transplanted rice cultivation can reduce nitrogen losses, which is more beneficial compared to broadcast method. Again, the deep placement of USG and NPK briquette minimizes the concentration of $\mathrm{NH}_{4}{ }^{+}-\mathrm{N}$ in floodwater compared to broadcast application of PU. The savings in applied $\mathrm{N}$ reached 70 and $35 \mathrm{~kg} \mathrm{ha}^{-1}$ when applied USG as $\mathrm{N}$ fertilizer during the Boro (February-June) and Aman (August-December) seasons, respectively (Bowen et al., 2005).

Water shortage is a growing problem due to climate change and upstream water regulation. On the other hand, nitrogen loss as ammonia volatilization in the flooded soils ranged from negligible to almost $60 \%$ of the applied N (Xing and Zhu, 2000). Shallow irrigation water depth has been recommended to lower the $\mathrm{NH}_{3}$ volatilization due to enhanced ammonium binding in the soil ( $\mathrm{Li}$ et al., 2008). In this case AWD is very effective. In some cases it was reported that AWD decreases yield by $5.4 \%$; however under mild AWD (i.e. when soil water potential was $\geq-20 \mathrm{kPa}$ or field water level did not drop below $15 \mathrm{~cm}$ from the soil surface), yields were not significantly reduced in most circumstances (Carrijo et al., 2017). The AWD practice has been found to have significant positive impact on yield of rice and minimize the production cost. Though it is advantageous to the farmers to minimizes the production cost with low $\mathrm{N}$ losses, limited information are available for AWD system (Djaman et al., 2018). 
Importantly, the efficient use of nitrogen is recognized as a production factor for rice, but it has always been a problem to improve the $\mathrm{N}$ utilization rate of the rice plant and to increase efficiency of absorbed nitrogen for grain production. Further, nitrogen fertilizer is costly, thus it is important to minimize the losses of nitrogen fertilizers and maximize the economic utility. Nitrogen use efficiency (NUE) of different rice cultivars such as BRRI dhan1 (Haque and Haque, 2016), BRRI dhan28, BRRI dhan36 (Alim, 2012), BRRI dhan29 (Hasan et al., 2016; Alam et al., 2010) has been studied.

Despite being a highly productive variety, NUE of BRRI dhan46 is barely reported. Considering the negative impact of inorganic fertilizers and yield of this rice variety, it is crucial to study the NUE and yield aspects for different dose of $\mathrm{N}$ fertilizers. This work was intended to study the NUE, grain yield, straw yield, apparent nitrogen recovery (ANR) and marginal benefit cost ratio for different doses to evaluate optimum dose.

\section{MATERIALS AND METHODS}

\section{Experimental site, weather, soil and variety}

The experimental site is located at Soil Science Field Laboratory of Bangladesh Agricultural University, Mymensingh, $24.75^{\circ} \mathrm{N}$ latitude and $90.5^{\circ} \mathrm{E}$ longitude, elevation $18 \mathrm{~m}$ above the sea level and is located in the agroecological zone (AEZ) of the Old Brahmaputra Floodplain. The average temperature, rainfall and relative humidity were respectively $26.4^{\circ} \mathrm{C}, 190.2 \mathrm{~mm}$ and $84.5 \%$. Since some of the attributes such as soil $\mathrm{pH}$, total nitrogen in soil, available phosphorus and exchangeable potassium reportedly affect NUE, it is important to quantify those attributes of experimental site (Chen et al., 2018). The selected field soil was a typical rice growing silt loam soil. The amount of total nitrogen in the soil was $0.136 \%$, available phosphorus $3.16 \mathrm{ppm}$, exchangeable potassium $0.095 \%$ and the $\mathrm{pH}$ 6.07 (Das et al., 2016). BRRI dhan46, a high yielding variety of rice was used as the test crop in this experiment. It is a transplant rice cultivar and matures after 150-155 days of transplanting with average dry yield 5.0-7.5 $\mathrm{Mt} \mathrm{ha}^{-1}$.

\section{Treatments}

The experiment was carried out with the following treatments: 
Table 1: List of treatments with different $\mathrm{N}$ fertilizers doses with their sources

\begin{tabular}{c|l|c|c}
\hline Treatments & \multicolumn{1}{|c|}{ Name of N Fertilizers } & $\begin{array}{c}\text { Amount of N } \\
\text { fertilizers }\left(\mathrm{kg} \mathrm{ha}^{-1}\right)\end{array}$ & STBRD-N (\%) \\
\hline $\mathrm{T}_{1}$ & None (Control) & - & - \\
$\mathrm{T}_{2}$ & PU (Prilled Urea) & 104 & 100 \\
$\mathrm{~T}_{3}$ & USG (Urea Super Granule) & 104 & 100 \\
$\mathrm{~T}_{4}$ & USG (Urea Super Granule) & 78 & 75 \\
$\mathrm{~T}_{5}$ & USG (Urea Super Granule) & 52 & 50 \\
$\mathrm{~T}_{6}$ & NPK briquettes & 104 & 100 \\
$\mathrm{~T}_{7}$ & NPK briquettes & 78 & 75 \\
$\mathrm{~T}_{8}$ & NPK briquettes & 52 & 50 \\
\hline
\end{tabular}

\section{Fertilizer applications}

All treatments were controlled for $\mathrm{N}$ only and before application of $\mathrm{N}$ fertilizers, the water in the rice plots was drained. Nutrients $\mathrm{P}, \mathrm{K}, \mathrm{S}$ and $\mathrm{Zn}$ were provided according to soil test recommendations and typical production demands. All treatments received $\mathrm{S}\left(18 \mathrm{~kg} \mathrm{ha}^{-1}\right)$ and $\mathrm{Zn}\left(3 \mathrm{~kg} \mathrm{ha}^{-1}\right)$ from gypsum and zinc oxide. Treatments $\mathrm{T}_{1}, \mathrm{~T}_{2}, \mathrm{~T}_{3}$, $\mathrm{T}_{4}$ and $\mathrm{T}_{5}$, received $\mathrm{P}\left(25 \mathrm{~kg} \mathrm{ha}^{-1}\right)$ and $\mathrm{K}\left(50 \mathrm{~kg} \mathrm{ha}^{-1}\right)$ from TSP $\left(\mathrm{Ca}\left(\mathrm{H}_{2} \mathrm{PO}_{4}\right)_{2}\right)$ and muriate of potash $(\mathrm{KCl})$, respectively. Treatments $\mathrm{T}_{6}, \mathrm{~T}_{7}$ and $\mathrm{T}_{8}, \mathrm{P}$ and $\mathrm{K}$ were supplied from NPK briquettes. The PU was applied in three equal splits. The first dose of PU was applied 10 days after transplanting (DAT), the second dose was added as top dressing at 35 DAT (active tillering stage) and the third dose was top dressed at 55 DAT (panicle initiation stage). USG and NPK briquettes were applied after 10 DAT. The USG and NPK briquettes were placed at $8-10 \mathrm{~cm}$ depth between four hills at alternate rows. Irrigation, weeding and other agronomic practices were done whenever necessary.

\section{Data collection and analysis method}

Data collected for analysis of variables were: plant height, effective tillers per hill, panicle length, grains panicle ${ }^{-1}$ and 1000-grain weight, grain and straw yield of BRRI dhan46 were recorded. For determination of yield attributes five hills were selected and number of tillers per hill, number of filled and unfilled grains per panicle and thousand grain weight was measured. The above ground plant parts were segmented into different components as leaf, stem, leaf sheath and panicle and were dried in an oven for 72 hours at $70^{\circ} \mathrm{C}$. After drying to $14 \%$ moisture, the grain yield of rice was measured as metric ton $\mathrm{ha}^{-1}$. The straw yield of rice was recorded as metric ton $\mathrm{ha}^{-1}$ 
on sun dry basis. For determination of total nitrogen semi-micro Kjeldahl method of Bremner and Mulvaney was used (Bremner and Mulvaney, 1982).

The NUE (kg grain yield increase $\mathrm{kg}^{-1} \mathrm{~N}$ applied) was determined by the following formula: $\mathrm{NUE}=\left(\mathrm{GY}_{+\mathrm{N}}-\mathrm{GY}_{0 \mathrm{~N}}\right) / \mathrm{FN} ;$ Where, $\mathrm{GY}_{+\mathrm{N}}=$ grain yield in treatment with $\mathrm{N}$ application, $\mathrm{GY}_{0 \mathrm{~N}}=$ grain yield in treatment without $\mathrm{N}$ application and $\mathrm{FN}=$ amount of fertilizer $\mathrm{N}$ applied $\left(\mathrm{kg} \mathrm{ha}^{-1}\right)$. The apparent $\mathrm{N}$ recovery was calculated by the following formula: ANR $\left(\mathrm{kg} \mathrm{ha}^{-1}\right)=\left(\mathrm{UN}_{+\mathrm{N}}-\mathrm{UN}_{0 \mathrm{~N}}\right) / \mathrm{FN}$; where, $\mathrm{UN}_{+\mathrm{N}}$ is total $\mathrm{N}$ uptake $\left(\mathrm{kg} \mathrm{ha}^{-1}\right)$ with grain and straw; $\mathrm{UN}_{0 \mathrm{~N}}$ is the $\mathrm{N}$ uptake $\left(\mathrm{kg} \mathrm{ha}^{-1}\right)$ in control; $\mathrm{FN}$ is amount of fertilizer $\mathrm{N}$ applied $\left(\mathrm{kg} \mathrm{ha}^{-1}\right.$ ) (Das et al., 2016). All the data were statistically analyzed by F-test and the mean differences were ranked by DMRT at 5\% level (Gomez and Gomez, 1984). All collected data were subjected to MSTAT-C software package to perform analysis of variance (ANOVA).

\section{RESULT AND DISCUSSION}

\section{Growth and yield contributing characters}

The growth of yield contributing characters such as, plant height, panicle length, tillers per hill, grains per panicle responded significantly due to application of USG and NPK briquette in comparison with PU (Table 2). The maximum plant height of $116.8 \mathrm{~cm}$ was recorded for treatment $\mathrm{T}_{6}$. The largest panicle $(24.35 \mathrm{~cm})$ was observed for $\mathrm{T}_{4}$ while the smallest panicle $(21.55 \mathrm{~cm})$ was observed in $\mathrm{T}_{1}$ (control). The maximum number of effective tillers hill $^{-1}(15.03)$ and grain panicle ${ }^{-1}(124)$ both were obtained from $\mathrm{T}_{3}$ which was similar with the result of rice cultivar BRRI dhan 28 (Islam et al. 2014). The number of filled grains panicle ${ }^{-1}$ varied from 91 to 124. However, the 1000-grain weight varied insignificantly due to application of PU, USG and NPK briquettes for BRRI dhan 46.

\section{Grain yield}

Remarkable response of the grain yield of BRRI dhan46 was found due to the deep placement of $\mathrm{N}$ fertilizers (Table 2). The grain yield ranged from $2.92 \mathrm{t} \mathrm{ha}^{-1}$ to $6.39 \mathrm{t}$ $\mathrm{ha}^{-1}$. The highest grain yield was recorded in $\mathrm{T}_{3}$ which was statistically similar to $\mathrm{T}_{4}$ and $\mathrm{T}_{6}$ and the lowest value was observed for control $\left(\mathrm{T}_{1}\right)$. 
Table 2: Effect of deep placement of $\mathrm{N}$ fertilizers in the form of USG and NPK briquettes compared to PU on the yield components and yield of BRRI dhan46.

\begin{tabular}{l|c|l|l|l|l|l|c}
\hline $\begin{array}{c}\text { Treatme } \\
\text { nts }\end{array}$ & $\begin{array}{c}\text { Plant } \\
\text { height } \\
(\mathrm{cm})\end{array}$ & $\begin{array}{c}\text { Panicle } \\
\text { Length } \\
(\mathrm{cm})\end{array}$ & $\begin{array}{c}\text { Tillers } \\
\text { hill }^{-1} \\
(\text { no. })\end{array}$ & $\begin{array}{c}\text { Grains } \\
\text { panicle } \\
(\text { no. })\end{array}$ & $\begin{array}{c}1000- \\
\text { grain } \\
\text { weight }(\mathrm{g})\end{array}$ & $\begin{array}{c}\text { Grain } \\
\text { yield } \\
\left(\mathrm{t} \mathrm{ha}^{-1}\right)\end{array}$ & $\begin{array}{c}\text { Straw } \\
\text { Yield } \\
\left(\mathrm{t} \mathrm{ha}^{-1}\right)\end{array}$ \\
\hline $\mathrm{T}_{1}$ & $97.84 \mathrm{c}$ & $21.55 \mathrm{~d}$ & $11.67 \mathrm{~d}$ & $91.00 \mathrm{~g}$ & $21.32 \mathrm{c}$ & $2.92 \mathrm{~d}$ & $5.63 \mathrm{~d}$ \\
$\mathrm{~T}_{2}$ & $109.85 \mathrm{~b}$ & $22.15 \mathrm{bcd}$ & $14.33 \mathrm{ab}$ & $117.00 \mathrm{bc}$ & $22.54 \mathrm{ab}$ & $4.48 \mathrm{c}$ & $7.26 \mathrm{~b}$ \\
$\mathrm{~T}_{3}$ & $115.16 \mathrm{ab}$ & $23.15 \mathrm{abc}$ & $15.03 \mathrm{a}$ & $124.00 \mathrm{a}$ & $22.65 \mathrm{a}$ & $6.39 \mathrm{a}$ & $8.38 \mathrm{a}$ \\
$\mathrm{T}_{4}$ & $115.42 \mathrm{ab}$ & $24.35 \mathrm{a}$ & $13.67 \mathrm{~b}$ & $115.33 \mathrm{~cd}$ & $22.55 \mathrm{ab}$ & $6.35 \mathrm{a}$ & $8.28 \mathrm{a}$ \\
$\mathrm{T}_{5}$ & $114.43 \mathrm{ab}$ & $23.43 \mathrm{ab}$ & $12.0 \mathrm{~d}$ & $108.67 \mathrm{e}$ & $22.50 \mathrm{ab}$ & $5.17 \mathrm{~b}$ & $7.56 \mathrm{~b}$ \\
$\mathrm{~T}_{6}$ & $116.81 \mathrm{a}$ & $24.07 \mathrm{a}$ & $13.67 \mathrm{~b}$ & $121.33 \mathrm{ab}$ & $22.19 \mathrm{~b}$ & $6.22 \mathrm{a}$ & $8.29 \mathrm{a}$ \\
$\mathrm{T}_{7}$ & $114.58 \mathrm{ab}$ & $23.41 \mathrm{ab}$ & $13.33 \mathrm{bc}$ & $112.00 \mathrm{de}$ & $21.49 \mathrm{c}$ & $5.24 \mathrm{~b}$ & $8.10 \mathrm{a}$ \\
$\mathrm{T}_{8}$ & $110.89 \mathrm{ab}$ & $21.73 \mathrm{~cd}$ & $12.33 \mathrm{~cd}$ & $100.00 \mathrm{f}$ & $21.46 \mathrm{c}$ & $4.42 \mathrm{c}$ & $6.20 \mathrm{c}$ \\
$* \mathrm{CV} \%$ & 2.91 & 3.83 & 4.51 & 2.3 & 0.96 & 2.91 & 2.94 \\
$* \mathrm{SE}( \pm)$ & 2.66 & 0.71 & 0.48 & 2.09 & 0.17 & 121.46 & 179.50 \\
\hline
\end{tabular}

Figures in a column having common letters do not differ significantly at $5 \%$ level of significance.

The percent increase of grain yield over control ranged from $34.02 \%$ to $54.34 \%$. Fig. 1 shows the percent increase of grain yield over control for all treatments. Similar results were found for some other varieties of rice (Huda et al., 2016), (Kapoor et al., 2008). For instance, in case of BRRI dhan 28 up to $97 \%$ increase over control was reported with the application of USG (Islam et al., 2014). Based on grain yield, the treatments may be ranked in the order of $T_{3}>T_{4}>T_{6}>T_{7}>T_{5}>T_{2}>T_{8}>T_{1}$. Deep placement of USG at the rate of $104 \mathrm{~kg} \mathrm{ha}^{-1}$ and at the rate $78 \mathrm{~kg} \mathrm{ha}^{-1}$ performed better in increasing grain yield of rice compared to PU and NPK briquette. Thus, the deep placement of $\mathrm{N}$ fertilizers demonstrated the most positive effect on grain yield. 


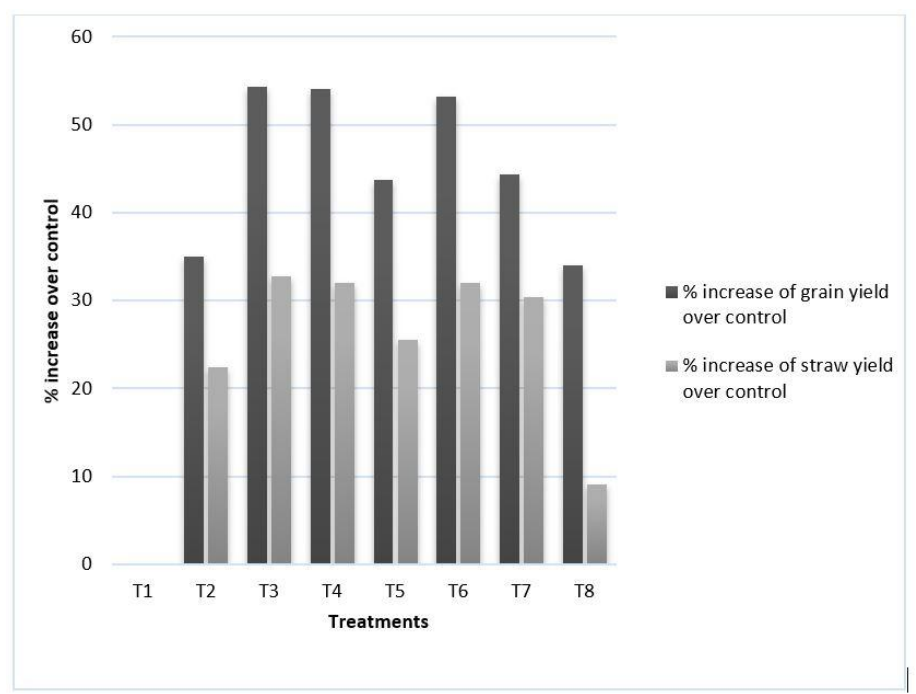

Fig.1 Bar diagram of the increase in per cent over control on the yield of BRRI dhan46 as influenced by the application of PU, USG and NPK briquettes.

\section{Straw yield}

Like grain yield, straw yield of BRRI dhan46 responded significantly to different treatments under study. The highest straw yield $\left(8.3 \mathrm{t} \mathrm{ha}^{-1}\right)$ was found in case of $\mathrm{T}_{3}$ and the lowest value $\left(5.6 \mathrm{t} \mathrm{ha}^{-1}\right)$ was observed for $\mathrm{T}_{1}$. From fig. 1 , we observed that nearly $9.06 \%$ to $32.7 \%$ increase in straw yield over control due to application of $\mathrm{N}$ either broadcast or deep placed. Similar to grain yield, the maximum increase of straw yield over control was found in $\mathrm{T}_{3}$. Based on straw yield the treatments may be ranked in order of $T_{3}>T_{6}>T_{4}>T_{7}>T_{5}>T_{2}>T_{8}>T_{1}$. Deep placement of USG (104 kg $\mathrm{ha}^{-1}$ ) performed better than other treatments in increasing straw yield under controlled irrigated conditions. The findings of the present study are well corroborated with the experiment of Das et al. (2016).

\section{Total $\mathbf{N}$ uptake}

As shown in Table 3 total $\mathrm{N}$ uptake both by grain and straw of BRRI dhan 46 was influenced significantly by the application of PU, USG and NPK briquettes under AWD condition. The total $\mathrm{N}$ uptake ranged from $50.49 \mathrm{~kg} \mathrm{ha}^{-1}\left(\mathrm{~T}_{1}\right)$ to $139.26 \mathrm{~kg} \mathrm{ha}^{-1}$ $\left(\mathrm{T}_{3}\right)$. The second highest total $\mathrm{N}$ uptake was recorded for $\mathrm{T}_{4}$. In this study we observed relatively lower amount of $\mathrm{N}$ uptake $\left(91 \mathrm{~kg} \mathrm{ha}^{-1}\right)$ for broadcast application of PU. The trend of $\mathrm{N}$ uptake conforms with the published work (Jahan et al. 2014). The total $\mathrm{N}$ uptake by BRRI dhan 46 due to different treatments may be ranked in the order of $T_{3}>T_{4}>T_{6}>T_{7}>T_{2}>T_{5}>T_{8}>T_{1}$. From this ranking, it is quite evident that the deep placement of $\mathrm{N}$ fertilizers increases the total $\mathrm{N}$ uptake by rice plant. 
Table 3. Effect of PU, USG and NPK briquette on N content and uptake of BRRI dhan 46

\begin{tabular}{c|ccc|ccc}
\hline \multirow{2}{*}{ Treatments } & \multicolumn{2}{|c|}{$\mathrm{N}$ content $(\%)$} & \multicolumn{3}{c}{$\mathrm{N}$ uptake $\left(\mathrm{kg} \mathrm{ha}^{-1}\right)$} \\
\cline { 2 - 6 } & Grain & Straw & Grain & Straw & Total \\
\hline $\mathrm{T}_{1}$ & $1.03 \mathrm{e}$ & $0.36 \mathrm{e}$ & $30.03 \mathrm{e}$ & $20.46 \mathrm{f}$ & $50.49 \mathrm{f}$ \\
$\mathrm{T}_{2}$ & $1.17 \mathrm{bc}$ & $0.53 \mathrm{c}$ & $52.72 \mathrm{~d}$ & $38.33 \mathrm{~d}$ & $91.04 \mathrm{~d}$ \\
$\mathrm{~T}_{3}$ & $1.37 \mathrm{a}$ & $0.62 \mathrm{~b}$ & $87.58 \mathrm{a}$ & $51.69 \mathrm{ab}$ & $139.26 \mathrm{a}$ \\
$\mathrm{T}_{4}$ & $1.32 \mathrm{a}$ & $0.58 \mathrm{~b}$ & $83.8 \mathrm{~b}$ & $48.34 \mathrm{~b}$ & $132.17 \mathrm{~b}$ \\
$\mathrm{~T}_{5}$ & $1.12 \mathrm{~cd}$ & $0.36 \mathrm{e}$ & $58.22 \mathrm{c}$ & $27.50 \mathrm{e}$ & $88.73 \mathrm{~d}$ \\
$\mathrm{~T}_{6}$ & $1.21 \mathrm{~b}$ & $0.66 \mathrm{a}$ & $75.60 \mathrm{~b}$ & $55.0 \mathrm{a}$ & $130.60 \mathrm{~b}$ \\
$\mathrm{~T}_{7}$ & $1.23 \mathrm{~b}$ & $0.53 \mathrm{c}$ & $64.29 \mathrm{c}$ & $42.96 \mathrm{c}$ & $107.25 \mathrm{c}$ \\
$\mathrm{T}_{8}$ & $1.09 \mathrm{de}$ & $0.42 \mathrm{~d}$ & $48.12 \mathrm{~d}$ & $26.22 \mathrm{e}$ & $74.34 \mathrm{e}$ \\
$* \mathrm{CV}(\%)$ & 2.98 & 4.59 & 4.91 & 5.01 & 4.27 \\
$* \mathrm{SE}( \pm)$ & 0.029 & 0.019 & 2.48 & 1.59 & 3.52 \\
\hline
\end{tabular}

Figures in a column having common letters do not differ significantly at $5 \%$ level of significance.

\section{Apparent $\mathrm{N}$ recovery (ANR)}

The apparent $\mathrm{N}$ recovery (ANR) indicates the absorption efficiency of applied $\mathrm{N}$. The ANR of BRRI dhan46 rice is presented in Fig. 2. Mean apparent recovery of $\mathrm{N}$ ranged from $38.31 \%$ to $85.35 \%$ in different treatments. The maximum value of ANR was obtained with the application of USG for treatment $T_{4}$ followed by $T_{3}, T_{6}, T_{7}$ and the minimum value was found in $\mathrm{T}_{2}$. The data presented in fig. 2 clearly reveals that the deep placement of USG and NPK briquettes enhance the recovery of applied N compared to broadcast application of $\mathrm{N}$ fertilizers.

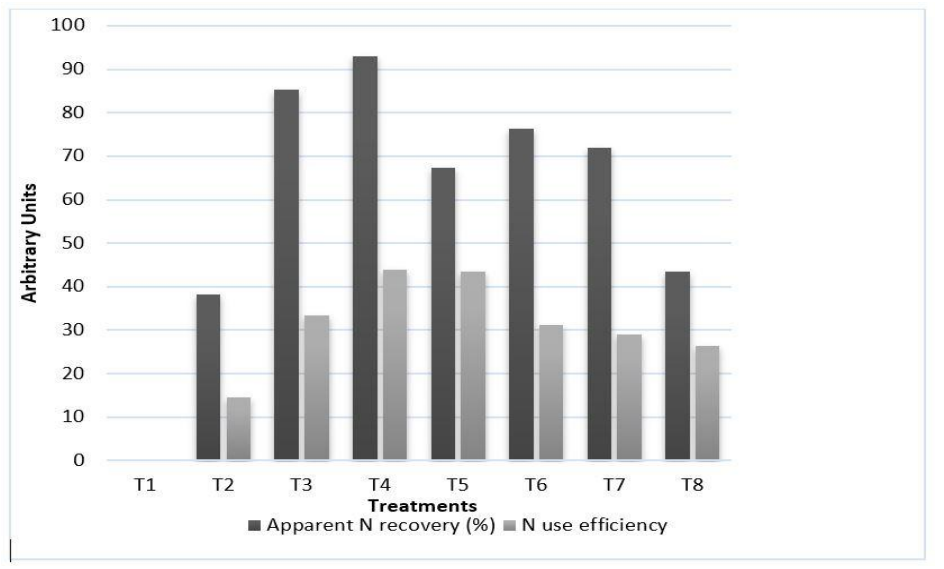

Fig. 2 Effects of PU, USG and NPK briquettes on apparent $\mathrm{N}$ recovery (\%) and $\mathrm{N}$ use efficiency of BRRI dhan46. 


\section{Nitrogen use efficiency (NUE)}

Agronomic NUE is used to indicate the relative balance between the amount of fertilizer $\mathrm{N}$ taken up and used by the crop versus the amount of fertilizer $\mathrm{N}$ lost. NUE represents the response of rice plant in terms of grain yield to $\mathrm{N}$ fertilizer. The maximum value of NUE (44.01 $\mathrm{kg}$ grain yield increase per $\mathrm{kg} \mathrm{N}$ applied) was obtained for $\mathrm{T}_{4}$ which is similar with the findings of (Hasan et al., 2016; Huda et al., 2016). Whereas, the minimum value was found in $T_{2}$ where, $14.46 \mathrm{~kg}$ grain yield increases for per $\mathrm{kg} \mathrm{N}$ applied. From the data it can be concluded that the deep placement of USG and NPK briquettes enhanced the NUE as compared to broadcast application of prilled urea.

\section{Economic analysis}

The marginal-benefit cost ratio (MBCR) of BRRI dhan46 as influenced by PU, USG and NPK briquettes has been presented in Table 4. MBCR is the ratio of marginal or added benefit and cost. To compare different fertilizers treatments with control, the following equation was used (Rahah et al., 2007):

$$
\mathrm{MBCR}=\frac{\text { Gross Income of Treatment }- \text { Gross Income of Control }}{\text { Gross Cost of Production (Treatment) }- \text { Gross Cost of Production(Control) }}
$$

The cost and return analysis of BRRI dhan 46 shows the highest marginal benefit-cost ratio of 2.95 was obtained from $\mathrm{T}_{4}$. The gross margin over control was maximum for $\mathrm{T}_{4}$ (555 USD ha ${ }^{-1}$ ). Considering the benefit-cost ratio and marginal benefit, $\mathrm{T}_{4}$ might be ranked first.

Table 4. Economic analysis of BRRI dhan46 as influenced by the application of PU, USG and NPK briquettes (1 USD = 80 BDT)

\begin{tabular}{|c|c|c|c|c|c|c|c|}
\hline \multirow[t]{2}{*}{ Treatments } & \multicolumn{2}{|c|}{$\begin{array}{l}\text { Yield } \\
\mathrm{Kg} \mathrm{ha}^{-1}\end{array}$} & \multirow{2}{*}{$\begin{array}{c}\text { Gross } \\
\text { return } \\
\text { (USD/ha) }\end{array}$} & \multirow{2}{*}{$\begin{array}{c}\text { Added cost } \\
\text { over control } \\
\text { (USD/ha) }\end{array}$} & \multirow{2}{*}{$\begin{array}{c}\text { Added benefit } \\
\text { over control } \\
\text { (USD/ha) }\end{array}$} & \multirow{2}{*}{$\begin{array}{c}\text { Gross } \\
\text { margin over } \\
\text { control } \\
\text { (USD/ha) }\end{array}$} & \multirow{2}{*}{$\begin{array}{l}\text { MBCR } \\
\text { over } \\
\text { control }\end{array}$} \\
\hline & Grain & Straw & & & & & \\
\hline $\mathrm{T}_{1}$ & 2918 & 5637 & 808.87 & - & - & - & - \\
\hline $\mathrm{T}_{2}$ & 4489 & 7267 & 1160.94 & 101.75 & 352.06 & 250.31 & 2.46 \\
\hline $\mathrm{T}_{3}$ & 6391 & 8380 & 1563.61 & 202.00 & 754.73 & 527.73 & 2.73 \\
\hline $\mathrm{T}_{4}$ & 6351 & 8285 & 1551.56 & 187.70 & 742.68 & 555.00 & 2.95 \\
\hline $\mathrm{T}_{5}$ & 5179 & 7569 & 1343.42 & 180.50 & 534.55 & 354.00 & 1.96 \\
\hline $\mathrm{T}_{6}$ & 6229 & 8290 & 1504.43 & 195.50 & 695.56 & 500.06 & 2.56 \\
\hline $\mathrm{T}_{7}$ & 5241 & 8101 & 1332.66 & 177.30 & 523.78 & 346.48 & 1.95 \\
\hline $\mathrm{T}_{8}$ & 4423 & 6199 & 1086.8 & 168.20 & 277.92 & 109.72 & 0.7 \\
\hline
\end{tabular}




\section{CONCLUSION}

This study was conducted using a highly cultivated rice variety of Bangladesh to maximize nitrogen use efficiency (NUE) without compromising the yield by employing eight treatments of three different $\mathrm{N}$ fertilizers on randomly selected plots. The overall result implies that the deep placement of USG $78 \mathrm{~kg} \mathrm{ha}^{-1}$ lead to the best grain yield, NUE and apparent $\mathrm{N}$ recovery of BRRI dhan46 with highest marginal benefit-cost ratio comparing with deep placement of NPK and broadcast application of PU. NPK briquettes, $104 \mathrm{~kg} \mathrm{ha}^{-1}$ also showed statistically similar grain yield but its marginal benefit cost ratio is lower than USG. Thus, USG $78 \mathrm{~kg} \mathrm{ha}^{-1}$ can be recommended as optimum dose for profitable cultivation of BRRI dhan 46.

\section{REFERENCES}

Alam, S.S., Moslehuddin, A.Z.M., Islam, M.R., and Kamal, A.M. (2010). Soil and foliar application of nitrogen for Boro rice (BRRIdhan 29). Journal of Bangladesh Agricultural University, 8:199-202.

Alim, M.A. (2012). Effect of Organic and Inorganic Sources and Doses of Nitrogen Fertilizer on the Yield of Boro Rice. Journal of Environmental Science \& Natural Resources, 5(1): 273- 282 .

Bangladesg Bureau of Statistics. (2015). Statistical Year Book of Bangladesh.

Bowen, W. T., Diamand, R.B., Singh, U., and Thompson, T.P. (2005). Urea deep placement increases yield and saves nitrogen fertilizer in farmers' fields in Bangladesh. Rice in Life: Scientific Perspectives for the 21st Century. Tsukuba, Japan.

Bremner, J.M., and Mulvaney, C.S.(1982). Methods of Soil Analysis Part 2. Madison, Wisconsin.

Carrijo, D.R., Lundy, M.E., and Linquist, B.A. (2017). Rice yields and water use under alternate wetting and drying irrigation: A meta-analysis. Field Crops Research, 203:173-180.

Chen, G., Cao, H., Liang, J., Ma, W., Guo, L., Zhang, S., Jiang, R., Zhang, H., and Goulding, K.W. T. (2018). Factors Affecting Nitrogen Use Efficiency and Grain Yield of Summer Maize on Smallholder Farms in the North China Plain. Sustainability, 10:118.

Das, S., Islam, M., Sultana, M., Afroz, H., and Hashem, M. (2016): Effect of deep placement of nitrogen fertilizers on rice yield and $\mathrm{N}$ use efficiency under water regimes. SAARC Journal of Agricultur, 13:161.

Djaman, K., Mel, V.C., Diop, L., Sow, A., El-namaky, R., Manneh, B., Saito, K., Futakuchi, K., and Irmak, S. (2018). Effects of Alternate Wetting and Drying Irrigation Regime and Nitrogen Fertilizer on Yield and Nitrogen Use Efficiency of Irrigated Rice in the Sahel. Water, 10.

Gomez, A.A, and Gomez, K.A (1984). Statistical procedures for agricultural research. Stat. Proced. Agricultural Research, 6:680. 
Haque, A., and Haque, M.M. (2016). Growth , Yield and Nitrogen Use Efficiency of New Rice Variety under Variable Nitrogen Rates. Scientific Research, 7:612-622.

Hasan, S.L., Islam, M.R., Sumon, M.H., and Huda, A. (2016). Deep placement of N fertilizers influences $\mathrm{N}$ use efficiency and yield of BRRI dhan29 under flooded condition. Asian Journal of Medical and Biological Research, 2:279.

Huda, A., Gaihre, Y.K., Islam, M.R., Singh, U., Islam, M.R., Sanabria, J., Satter, M.A., Afroz, H., Halder, A., and Jahiruddin, M. (2016). Floodwater ammonium, nitrogen use efficiency and rice yields with fertilizer deep placement and alternate wetting and drying under triple rice cropping systems. Nutrient Cycling in Agroecosystems, 104:53-66.

Islam, M.R., Akter, M., Sumon, M.H., Das, S., and Huda, A. (2014). Effect of deep placement of $\mathrm{N}$ fertilizers on yield and nitrogen use efficiency of boro rice cv, BRRI dhan28. Bangladesh. Journal of Crop Science, 26:1-7.

Jahan, N., Islam, M.R., Siddique, A.B., Islam, M.R., Hassan, M.M., Shamsuzzaman, S.M. and Samsuri, A.W. (2014). Effects of integrated use of prilled urea, urea super granule and poultry manure on yield of transplant aus rice and field water quality. Life Science Journal, 11:101-108.

Kapoor, V., Singh, U., Patil, S., Magre, K.H., Shrivastava, L.K., Mishra, V.N., Das, R.O., Samadhiya, V.K., Sanabria, J., and Diamond, R. (2008). Rice growth, grain yield and floodwater nutrient dynamics as affected by nutrient placement method and rate. Agronomy Journal, 100:526-536.

Li, H., Liang, X., Chen, Y., Tian, G., and Zhang, Z. (2008). Ammonia volatilization from urea in rice fields with zero-drainage water management. Agricultural Water Management, 95:887-894.

Rahah, K., Santhi, P., and Ponnuswamy, K. (2007). Economic feasibility of drip irrigation in maize- sunflower- beet root cropping system. International Journal of Tropical Agriculture, 27:132.

Savci, S. (2012). Investigation of Effect of Chemical Fertilizers on Environment. APCBEE Procedia, 1:287-292.

Singh, B.K., and Trivedi, P. (2017). Microbiome and the future for food and nutrient security. Microbial Biotechnology, 10:50-53.

Xing, G.X., and Zhu, Z.L. (2000). An assessment of N loss from agricultural fields to the environment in China. Nutrient Cycling in Agroecosystems, 57:67-73. 